\title{
DEVELOPMENT OF COLLECTIVE TRADEMARK FOR BATIK INDUSTRY IN KAMPUNG BATIK LAWEYAN (LAWEYAN BATIK'S VILLAGE), SOLO
}

\author{
Agus Sardjono*, Brian Amy Prastyo**, Derezka Gunti Larasati ${ }^{* * *}$
}

\footnotetext{
* Professor on Intellectual Property Rights Law and Private Law, Faculty of Law, Universitas Indonesia.

** Lecturer of Intellectual Property Rights Law, Cyber Law, and Insurance Law, Faculty of Law, Universitas Indonesia.

*** Teaching Assistant on Intellectual Property Rights Law and Commercial Law, Faculty of Law, Universitas Indonesia.
}

\begin{abstract}
Article Info
Received : 26 February 2015 | Received in revised form : 23 April 2015 | Accepted : 23 April 2015

Corresponding author's e-mail : agussardjono@yahoo.com, brian.prastyo@ui.ac.id,derezka.larasati@ ui.ac.id
\end{abstract}

\begin{abstract}
Previous research found that the individual trademark system has not been effectively utilized to support the business of batik Smal Medium Enterprises (SMEs), particularly in several batik industry centers in Java, namely Bantul in Yogyakarta province, Kauman in Pekalongan and Laweyan in Solo. However, the fact that those SMEs gather in a community, organization, or kinships bring potentials for development of collective trademarks, which can address the problems that individual trademark cannot anticipate. The development of collective trademark can also be a strategy to anticipate the free-trade 'attack,' i.e. imported textiles with batik patterns/motifs; which are not the original Indonesian batik. In regards to that, Indonesian batik SMEs need to be nurtured and encouraged to register their own collective trademarks and to build their branding infrastructure, through local batik community's standardization, and collective batik labeling. This present research focuses on the development of collective trademark utilization by one longknown batik community in Kampung Batik Laweyan, Solo, as a strategy to enable them to compete with imported batik-printed textiles, as well as to protect their traditional batik cultural heritage.
\end{abstract}

Keywords: collective trademark, batik, SME, trademark, geographical indications

\begin{abstract}
Abstrak
Hasil penelitian sebelumnya menunjukkan bahwa sistem merek individual belum secara efektif digunakan untuk mendukung Usaha Kecil Menengah (UKM) yang bergerak di industri batik, khususnya di beberapa pusat industri batik di Jawa, yakni Bantul di Daerah Istimewa Yogyakarta, Kauman di Pekalongan dan Laweyan di Solo. Namun demikian, fakta bahwa UKMUKM batik tersebut berkumpul dalam sebuah komunitas, organisasi atau dalam hubungan kekerabatan, menunjukkan adanya potensi untuk mengembangkan merek kolektif, yang mana dapat digunakan untuk menyelesaikan permasalahan yang tidak dapat diatasi oleh sistem merek individual. Dengan mengembangkan merek kolektif, hal ini juga dapat menjadi sebuah strategi untuk mengantisipasi serangan perdagangan bebas. Misalnya tekstil impor dengan pola batik; yang sebenarnya bukanlah termasuk batik asli Indonesia. Sehubungan dengan hal tersebut, UKM-UKM batik Indonesia harus diayomi dan dihimbau untuk mendaftarkan merek kolektif mereka dan untuk membangun prasarana pemasaran, melalui standarisasi komunitas batik lokal dan pendaftaran merek kolektif. Penelitian yang dibahas dalam artikel ini berfokus pada perkembangan penggunaan merek kolektif oleh sebuah komunitas batik yang telah lama terbentuk di Kampung Batik Laweyan, Solo, sebagai sebuah strategi untuk dapat bersaing dengan tekstil berpola batik yang diimpor, sekaligus sebagai upaya perlindungan atas warisan tradisional budaya batik.
\end{abstract}

Kata Kunci: merek kolektif, batik, UKM, merek, indikasi-geografis. 


\section{Introduction: Insight on the Trademark Utilizations by Batik SMEs}

During the last 5 (five) years, Indonesia's domestic markets were filled up by imported 'batik' products from other countries. ${ }^{1}$ Those imported products, which local batik communities mention as (only) 'textille with batik pattern/motifs,' came from China and Malaysia. Data from Indonesia's Center of Statistic Agency (Badan Pusat Statistik - BPS) stated that 1.037 tons of imported 'batik' from China entered Indonesia's markets in 2012. ${ }^{2}$ To this date, many imported 'batik' can still be found in the markets. This phenomenon has worried some of the local batik Small Medium Enterprises (SMEs), since the imported 'batik' products are sold at cheap prices, and can be produced quickly in massive numbers. ${ }^{3}$ Their concerns are reasonable, since the consumers are difficult to be able to differentiate between the local batik and the imported ones. Consumers or buyers tend to choose the products with cheaper prices. Since the imported 'batik' products are cheaper than the local products, many of the consumers then buy them rather than the local ones. ${ }^{4}$ This has diminished local batik's selling values. The local SMEs have to lower down their selling prices in order to compete with those imported 'batik'. This is an irony since the imported 'batik' and the local batik products have an essential difference. The difference is that the imported 'batik' products are not Batik Indonesia. Just as the local batik SMEs stated, those imported ones are only 'textille with batik pattern/motifs' and they do not possess the cultural characteristic and qualities which batik of Indonesia has. ${ }^{5}$ Stating

1 This phenomenon was discussed in some electronic and printed press. See Riza Khairi, "Batik China dan Bawang Putih Impor Banjiri Indonesia, Ini Tanggapan Bos Kadin,” http://suarapengusaha. com/2013/02/27/batik-china-dan-bawang-putih-impor-banjiri-indonesia-ini-tanggapan-bos-kadin/ dated 11 Maret 2013 and Detikfinance (1), "RI Digempur Batik China Sejak 4 Tahun Lalu," http://finance. detik.com/read/2013/02/20/133528/2175015/4/ri-digempur-batik-china-sejak-4-tahun-lalu, dated 20 Februari 2013. It has also been said by the Minister of National Development Planning / Head of Bappennas, Armida Alisjahbana, that the imported batik products entering Indonesia's market are not the original batik of Indonesia, because they are only textiles printed with batik patterns, and the creation of the imported batik products did not involve any traditional batik making process (Detikfinance (2), "Tanggapi Serbuan Batik Impor, Menteri Bappenas: Itu Bukan Batik!” http://finance.detik.com/read/2013/02/20/ $115057 / 2174877 / 4 /$ tanggapi-serbuan-batik-impor-menteri-bappenas-itu-bukan-batik) dated 20 February 2013.

2 The Indonesian Way, "Impor Batik dari China Mencapai Rp 285 Miliar" (Imported Batik from China Reached IDR 285 billions), http://www.theindonesianway.com/impor-batik-dari-china-mencapairp-285-miliar/ accessed 26 June 2013. The chairman of Indonesia's Textille Association (Asosiasi Pertekstilan Indonesia), Ade Sudrajat, stated that the 'attack' of imported 'textille with batik patterns/motifs' to Indonesia's local markets have happened since 4 years ago. Such imported products are being sold at cheap prices; weaken the competitive power of local batik products, which generally have higher prices than the imported ones.

3 Okezone, “Gubernur Jateng Keluhkan Serbuan Batik Impor China,” http://jakarta.okezone. com/read/2011/10/03/320/510056/gubernur-jateng-keluhkan-serbuan-batik-impor-china, accessed 25 June 2013; and RMOL, "Batik China dan Jiran Ganggu Daya Saing Produk Lokal," http://ekbis.rmol. co/read/2011/08/03/35131/Batik-China-\&-Jiran-Ganggu-Daya-Saing-Produk-Lokal-, accessed 25 June 2013. This capability of imported 'batik' traders is also confirmed by the SMEs that are being interviewed during this study.

${ }^{4}$ These findings were revealed when researchers conducted field studies interviewing samples of Batik SMEs in Thamrin City, Jakarta. Some of Batik SMEs in Thamrin City stated that they often explained the differences between original Indonesian Batik and the printed-imported textiles to the consumers buying their products.

${ }_{5}^{5}$ The field studies which were conducted in three areas in Java: Yogyakarta, Solo, and Pekalongan, reveal the concerns of Batik SMEs toward the 'textille with batik pattern/motifs.' Among their concerns is: the printed textilles are averagely much cheaper, thus being preferred by the consumers who cannot differentiate the textilles with the real Batik Indonesia. Even so, some of the SMEs also mentioned that Batik 
the textilles as 'batik' will undervalue the prolonged existence of Batik Indonesia's culture and traditions.

The imported 'batik' can have similar pattern/motifs with local batik; however they are made using machines. The patterns/motifs are being printed on the cloths; making them similar to other mass textile products of garment industry. On the other hand, batik cloths are made through traditional craftmanships; by applying dots and lines of hot wax (refers to malam in Bahasa Indonesia's term) to the cloth using a copper pen-like instrument named canting tulis, or copper stamps named canting cap, as a resist to hand-dyeing later removed by boling and/or scrapping. ${ }^{6}$ Batik clothings which are made using canting tulis (pen-like instrument) is called batik tulis, whereas those which are made using canting cap (stamp-like instrument) is called batik cap. Those two products are considered as Batik Indonesia. ${ }^{7}$ The process explained above is repeated for each color which will be applied into the cloth. The more combinations of color are used, the more the application of hot wax and hand-dyeing process are repeated. Therefore, cloths with batik patterns/motif that are not made through such process cannot be considered as batik, and the traders or companies making such printed textilles of batik patterns/motif should not be using the term 'batik' to market their products in Indonesia. ${ }^{8}$

The utilization of trademarks may become one solution to protect the local batik products, as well as to strengthen the position of batik SMEs while competing with traders of imported 'batik.' In this context, the use of trademarks can help indicating local batik SMEs products as compared with the imported 'batik.' Trademarks can indicate the source of batik products, whether coming from local SMEs or from foreign companies. Further, trademarks then can also be used to indicate/distinguish which products are batik of Indonesia, or which are only imported textiles printed with batik patterns/motifs. From the perspective of consumers, the use of trademarks as instruments to mark local batik and imported 'batik' can help them understand the essential difference between the two, and make them aware of the cultural traditions surrounding batik.

In this case, the use of trademarks may at least serve for these two functions: (1) as an identification mark to distinguish local batik products with those of imported textiles, and (2) as a distinguishing mark for each of batik SMEs in correlation with their quality and characteristic of batik products. The trademarks then can support the SMEs promotion and marketing of their products, including while

Indonesia do have its own market, with segmented consumers who apparently understand and value the real Batik Indonesia. The studies will be further elaborated inelaborated in this paper.

${ }^{6}$ UNESCO Intergovernmental Committee for the Safeguarding of the Intangible Cultural Heritage, "Nomination for Inscription on the Representative List in 2009 (Reference No. 00170)," (Convention for the Safeguarding of the Intangible Cultural Heritage, Fourth Session, Abu Dhabi, United Arab Emirates, 2009).

${ }^{7}$ Hamzuri, Batik Klasik (Classical Batik), $3^{\text {rd }}$ ed., (Jakarta: Djambatan, 1989), pp. 16-17 and UNESCO Intergovernmental Committee for the Safeguarding of the Intangible Cultural Heritage, "Nomination for Inscription on the Representative List in 2009 (Reference No. 00170)," (Convention for the Safeguarding of the Intangible Cultural Heritage, Fourth Session, Abu Dhabi, United Arab Emirates, 2009).

8 To summarize, the process of making batik cloth starts with drawing patterns (mola), applying hot wax into the patterns with various shapes or motifs using canting into each side of the cloth, applying hot wax into the parts of cloth which will not be colored, hand-dyeing of cloth for applying colors, removing hot wax from the parts that will be hand-dyed into other colors, applying hot wax into the parts that will keep the original or first dyed-color, then boiling the dyed-cloth to remove all its hot wax. See Hamzuri, loc. cit., and see also Forum Pengembangan Kampung Batik Laweyan, "Batik Tulis," http://www.kampoenglaweyan.com, accessed 17 July 2013. 
competing with imported textile traders in domestic markets. The strengthening of SMEs' entrepreneurship through trademarks utilization for reputation building and development of branding infrastructure is a part of proposed action to prepare Indonesia's batik SMEs cope with free-trade market in the next 2015.

However, the previous research conducted in 2013 which took samples of batik SMEs in three areas: Yogyakarta, Pekalongan, and Solo, indicates that most of batik SMEs have not been utilizing their trademarks effectively. They have owned individual trademarks but most of them have not registered their trademarks to Directorate General of Intellectual Property Rights of Indonesia (DGIPR Indonesia). Many of them also only use the trademarks for trade names. The research also shows that in general they have not been familiar with the administrative process for trademark registration including the fees needed for application. The respondents of Batik SMEs were coming from several areas in the three provinces, and below is the composition:
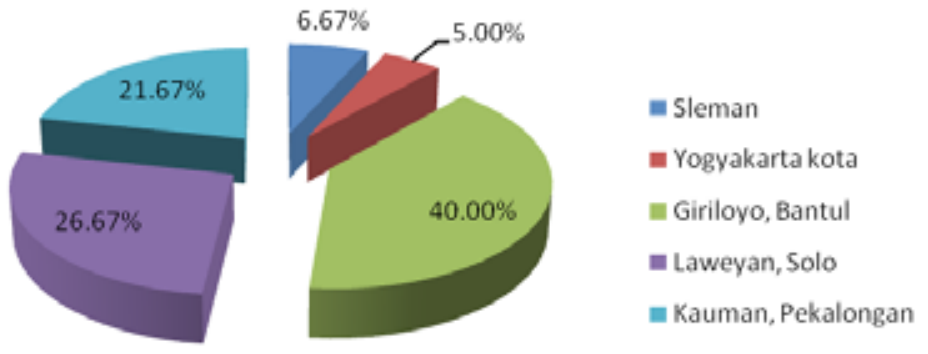

Graph 1: Percentage of Respondent Batik SMEs based on Areas in Field Study

From the respondent of batik SMEs in such targeted areas, the research found as follows:

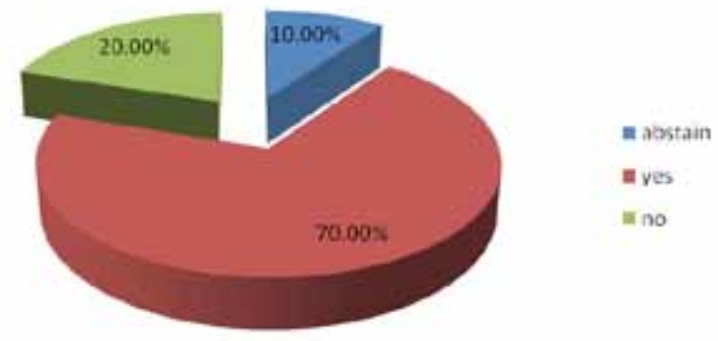

Graph 2: Percentage of Respondent Batik SMEs Having Trademarks 


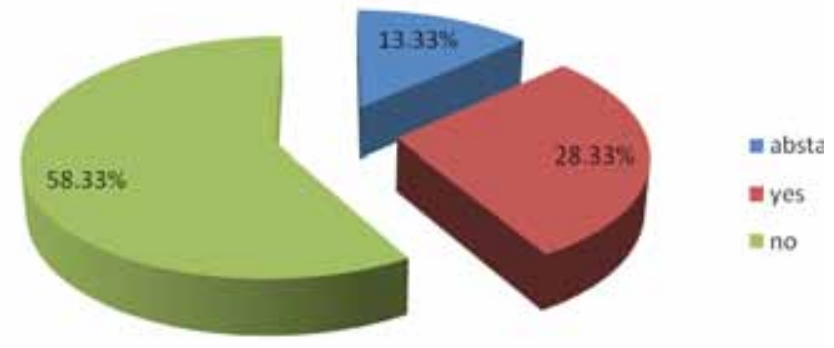

Graph 3: Percentage of Respondent Batik SMEs Having Their Trademarks Registered at DGIPR Indonesia

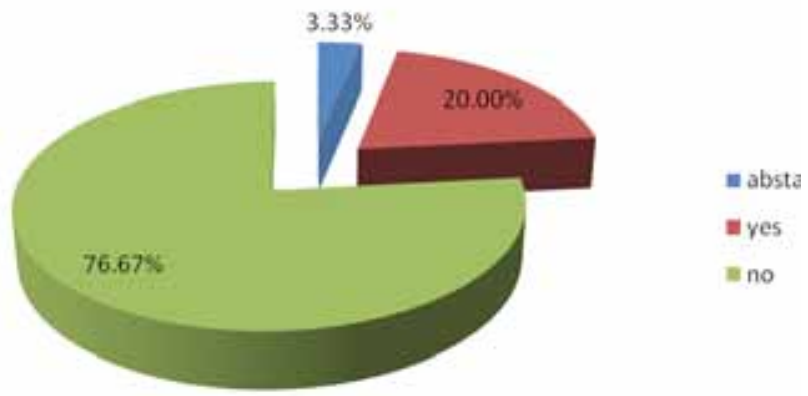

Graph 4: Percentage of Respondent Batik SMEs who knows the amount of trademark's registration costs at DGIPR

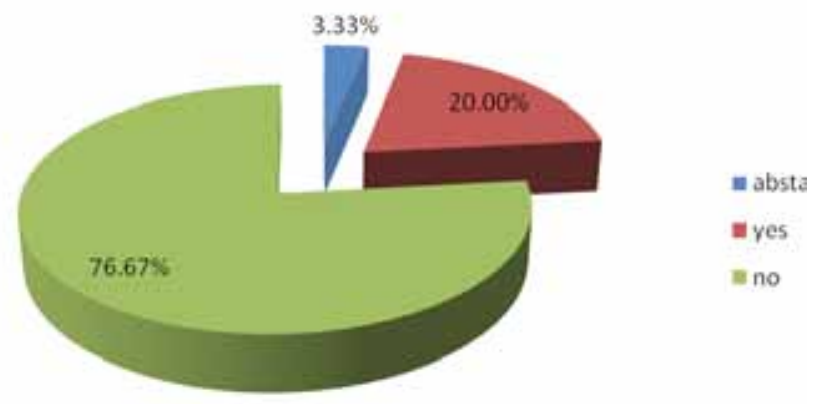

Graph 5: Percentage of Respondent Batik SMEs who knows the administrative requirements for trademark registration at DGIPR 
The analysis on surveys to the respondents of Batik SMEs indicates that most of them have already had trademarks functioned as trade names. Yet, only some numbers of them have registered their trademarks. The SMEs reluctance in government's complicated and costly bureaucracy becomes one of the reasons why they have not registered their trademarks. ${ }^{9}$ Such reason and the argument that they 'do not need' their trademarks to be registered, keep the number of trademark registrations low at DGIPR. ${ }^{10}$ As for those who consider they do not need the registration, they still consider the scale of their business are still small and the trademarks have not become important for the products' sales. This means that they will register their trademarks when their business scale has gone bigger. Among those who include themselves as small business are the craftsmen/craftswomen who only produce batik for other showrooms (bigger SMEs) based on orders. Their main objectives are basically economic income, and batik orders from other SMEs are being considered as one important source of income, even though it brings implication of their inability to use their own labels on the products. ${ }^{11}$

Moreover, some of the SMEs also have thoughts that the use of trademark and its registration cannot guarantee any improvement to the sales and they think that consumers buy batik products based on the choices of motifs/patterns, and not solely because of such batik's trademarks. For the SMEs which only have small business, they do not have sufficient money or capital to open a dedicated showroom, including promoting and advertising their own batik trademarks, as well as hire paid workers to assist them in managing or administering technical things, such as trademarks registration and promotion, or showroom management.

At certain point, those above mentioned issues have made the individual trademarks system cannot be effectively utilized by batik SMEs. Considering the structure of community and the SMEs' business nature, the collective trademark system may be used to tackle those issues. ${ }^{12} \mathrm{~A}$ well-known batik industry village in

9 These reasons were revealed from the interviews and discussions which researchers held with the respondents of Batik SMEs.

10 Interviews with the respondent of Batik SMEs in Thamrin City, Jakarta, and Yogyakarta, found that the SMEs consider the main reason why consumers decide to buy their batik products is not because of the trademark they have, but because of the motifs of their batik products.

11 The bigger SMEs, which make orders to the smaller ones, are those who will use their labels/ trademarks in the products.

${ }^{12}$ Prior art research regarding IPR utilization by SMEs of pearl craftsmen/craftswomen in Amuntai and Lombok, West Nusa Tenggara (Nusa Tenggara Barat) province, found out that the there is a living value among the craftsmen/craftswomen that indicates a communal characteristic, either in regards to the sharing of knowledge in making of pearl handicrafts, or imitation of crafts' designs, which are not considered as a legal problem for them. It was also found that the craftsmen/craftswomen are gathered in a community, who live in the same area and be known as a community of pearl handicrafts producers. See Agus Sardjono, et.al., "Pemanfaatan Hak Kekayaan Intelektual Oleh Pengusaha Kerajinan Mutiara di Lombok dan Kerajinan Rotan di Amuntai (Intellectual Property Rights Utilization by Pearl Craftsmen in Lombok, and Rattan Handicrafts in Amuntai)," (Primary Grant Report of University of Indonesia's Leading Research Year 2012, Faculty of Law, University of Indonesia) and Agus Sardjono, "Membangun Sinergi dalam Mengembangkan Industri Kreatif: Suatu Pendekatan Hukum (Empowering Synergy to Develop the Creative Industry: A Legal Approach)," (Final Report of National Strategic Research Grant Year 2009). Furthermore, another research focusing on Indonesian ethnic societies by Hokky Situngkir, titled "Evolutionary Clustering in Indonesian Etchnic Textile Motifs," also describes the phenomena of communalities, and each of the community residing at particular area has a distinguishing characteristic of textile motifs. For instance, motifs of batik cloths in Java will be different with motifs of songket cloth from Sumatra. This relates to what Tulus Tambunan mentions in his book regarding SMEs in Indonesia; SMEs producing similar goods are usually located near to each other, or also called as 'cluster'. Each local area may be famous for different cluster of products of 
Solo, Central Java area, has begun to work on a utilization of collective trademark by its community. The following section will elaborate the development process of such community's collective trademark.

\section{Batik Industry in Kampung Batik Laweyan, Solo}

Kampung Batik Laweyan has been long famous for its inland batik(Batik Pedalaman) production. ${ }^{13}$ The history of Laweyan recalls for a community of batik traders with women having a vital role in running the business, which are usually called as mbok mase or nyah nganten, and their husbands as mas nganten to support the family's unity. ${ }^{14}$ Laweyan's products are comprised of: batik cap (stamped batik), batik tulis (written batik), combination of stamped and written, and variety of (combined / noncombined) batik printing. ${ }^{15}$ The industry vastly grows with the development of batik cap. The motifs in batik cap are made using copper stamps. According to the data of 2011 obtained from the village's organization, Forum Pengembangan Kampung Batik Laweyan (or FPKBL), currently there are 92 batik SMEs in the area, which focus on: batik-processing (workshops), garment production, and showrooms or stores. ${ }^{16}$ Some of them may focus on all the fields, i.e. from batik-processing to showroom, but there are also those who focus only on one or two of them.

The previous field research drawn insights about the nature of batik businesses in Laweyan. They started from a family business, which scale is ranging from small to medium-sized enterprises with varied activities:

1. Workshops and showrooms at their houses;

2. Workshops only; provide cloths to be sold either in its original form, or as the materials for clothing productions;

3. Clothing production from batik cloths (garment-processed), with or without showrooms;

4. Showrooms only, selling various kinds of batik cloths/clothing;

5. Workshops and clothing productions, with or without showrooms, and/or Batik handicrafts.

craftsmanships. In this context, cluster of SMEs in particular area of Sumatra will be known as the center for songket cloth production, as well as how Bantul in Yogyakarta, Kauman in Pekalongan, or Laweyan in Solo as centers for batik industry are known to be clusters for batik productions.

13 Batik Kraton Jawa can also be called as inland batik (batik pedalaman), and represents the artistic and esthetique quality of Javanese culture. This batik uses soil-nuance colors such as black, chocolate, and old yellow (or 'soga'), with (sometimes) white background. The style of its pattern is organized/ orderly and geometrical. The symbols or motifs in Batik Kraton's patterns contain philosophical meanings and during old times not all people can wear batik cloth that has such particular symbols or motifs. The Javanese Court's (Kraton Jawa) family members were the ones who could wear batik cloth with those particular symbols or motifs. The two cities in Java having the court's system and culture are Yogyakarta and Solo (or Surakarta, historically Surakarta's Court - Kasunanan Surakarta) (Evi Steelyana, "Batik, A Beautiful Cultural Heritage that Preserve Culture and Support Economic Development in Indonesia," Binus Business Review Vol. 3 No. 1 (May 2012): 121.

${ }^{14}$ Forum Pengembangan Kampung Batik Laweyan, “Sosial Budaya - Kampoeng Laweyan,” http:// www.kampoenglaweyan.com, accessed 17 July 2013.

15 Naniek Widyawati, Settlement of Batik Enterpreneurs in Surakarta (Yogyakarta: Gadjah Mada University Press, 2004), pp. 39 - 41.

16 This data was received from the representative of Kampung Batik Laweyan's organization, Forum Pengembangan Kampung Batik Laweyan (or FPKBL), during the field research. 
As for the structure of the community, Laweyan batik SMEs are residing in one village (Kampung Batik Laweyan), and they gather in batik village's organization (FPKBL) which serves for Laweyan's batik and village development. ${ }^{17}$ Previous research also found that batik SMEs in Laweyan have better awareness and understanding on the importance of trademarks utilization and registration. Many of the SMEs in Laweyan have already registered their trademarks. As family business having both workshop and showroom with a particular trademark, they have a vision towards entrepreneurship and development of business, including quality control of the products. For instance, some of them have applied the national standard (Standar Nasional Indonesia - Indonesian National Standard) for batik products in order to wellcompete in the market, including for exports. ${ }^{18}$ Having strong historical background of batik culture as a community of traders, Laweyan SMEs have a profound awareness on their identities and cultural traditions in batik creation. As a community, they also keep developing the community's batik culture and business through their organization, FPKBL. Laweyan SMEs also consider themselves as having different characteristic and quality compared with batik SMEs from other areas. These strong community and cultural bounds, as well as entrepreneur visions make them much well-prepared for development and utilization of collective trademark.

\section{Collective Trademark Registration for Laweyan Batik Industry}

According to the article 1 point point 4 of Law regarding Trademarks, Law No. 15 Year 2001, SG No. 110 Year 2001 ("Trademark Law"), collective marks/trademarks are the mark which is being used for certain products and/or services having similar characteristics which are being traded by group of people or entities altogether. In this context, the SMEs residing in a particular cluster and/or gathered in a community with similar craftsmanship's products may utilize and develop their own collective trademarks. The collective trademarks are usually used by the members of group or association/organization which is involved in the trading activities of such similar products or services. In order to use the trademark together, the members need to have an agreed terms and conditions, or rules, regarding the use of the trademark, such as only for particular types of products or services with certain qualities or characteristics. This set of rules are also important to maintain the quality and characteristic that the products should have, so that if in any case, any member cannot comply with the rules, its right to use the collective mark may be revoked. Furthermore, if there are other SMEs outside the association/organization who want to become the member, and produce the goods which use the collective mark, such new SMEs then also need to comply with the collective trademark rules.

The association or organization in where the members are gathered, usually acts as the facilitator in the making of collective mark utilization's agreed rules, as well as taking roles in monitoring the use of such mark, so that the member's products or services which use the mark will continuously comply with the agreed rules. Article 50 paragraph (3) of the Trademark Law stipulates that collective trademark rules ${ }^{19}$

17 The research was conducted in 2013, focusing on the implementation of Trademark Law for Batik SMEs in Solo, Yogyakarta and Pekalongan. The method used was a combination of qualitative and quantitative research with empirical data.

18 The Chairman of FPKBL, Mr. Alpha Febela, owner of Batik Mahkota Laweyan, is an example of Laweyan's Batik SMEs who has gained the certification of Indonesian National Standard (SNI) for its batik products.

19 The World Intellectual Property Organization (WIPO) refers the collective trademark rules as 
should at least regulate:

a. Characteristic, general features or certain qualities of the products or services being produced and traded;

b. Effective monitoring on the use of trademark, and

c. Penalty for the use of trademark which infringes the collective trademark rules.

In Indonesia, the association or organization can apply for collective trademark registration to DGIPR on behalf of its members. For such registration, the association needs to list all of its members who will be using the collective mark. The association or organization is not run by an independent party or a third party, but is run by the members of the association or organization itself, who are the SMEs which produce and/or engage in the products' trading activities and which will also be using the collective mark.member ${ }^{20}$ The collective trademark system has advantages in regards to the cost of trademark registration and marketing activities. If the SMEs file the application of trademark registration by itself, the cost will be higher and may discourage them to administer the registration. However, if it is in the form of collective mark, they can bear all the cost of registration altogether. The difficulties of the process can also be handled together. The community's representatives or those who have better understanding on the registration's process can support the others. As an individual SME, difficulties they have in promoting their brands and marketing of products to distributors or consumers can also be tackled together if they gather as a collective group with the same trademark. ${ }^{21}$ One necessary requirement to achieve such collectivity is of course, they have to produce goods or services which have similar characteristics with each other. ${ }^{22}$ This nature of collectivity, or collective community, is also in harmony with the living value of Indonesian society, that is the mutual cooperation (or in Bahasa Indonesia, 'gotong royong').

In Laweyan, where the SMEs have already gathered in an organization forum (FPKBL) for development of Laweyan as a batik village; organizing, maintaining, and controlling the use and utilization of community's collective trademark will considerably easier. The strong cultural characteristic from the community will also give them advantage in building their own brand as a distinguished 'Laweyan batik.' Aside from using their own individual (registered or non-registered) trademarks or trade names, they can also use the collective trademark to signify their existence as a community of batik producers with Laweyan characters or qualities organized under their own forum, FPKBL. Under the forum, they also can develop the necessary infrastructure of products' branding and marketing as well as maintaining the quality standards. Laweyan batik community can also sustainably construct their own standards on batik products' characters and quality which can distinguish them from

\footnotetext{
"The Regulation Concerning the Use of Collective Mark".

20 Alison Firth, et.al., Trade Marks, Law and Practice, $3^{\text {rd }}$ ed., (Bristol: Jordan Publishing Limited, 2012), pp. $241-242$.

21 World Intellectual Property Organization, "Making a Mark: An Introduction to Trademarks for Small and Medium-sized Enterprises," Intellectual Property for Business Series No. 1, http://www.wipo.int/ export/sites/www/sme/en/documents/guides/translation/making a mark indo.pdf, accessed 4 July 2013.

22 One of the objectives of collective trademark system is to simplify the registration of individual applications. For example, if 10 companies produce goods with similar characteristics, then they can apply one trademark registration altogether to be used by all of them. See M. Yahya Harahap, Tinjauan Merek Secara Umum dan Hukum Merek di Indonesia Berdasarkan Undang-Undang No. 19 Tahun 1992 (Legal Study on Trademark Law in Indonesia Based on the Law No. 19 Year 1992), (Bandung: Citra Aditya Bakti, 1996), p. 604 .
} 
other batik products of other areas. To attach the collective mark into their products, aside from mark labels, they can also create a specific batik shape or motif as the logo which then be stamped or painted (using the canting and hot-wax) in all of their products. Through these methods of utilizing the collective trademark, the consumers then can get information and recognize batik products which come from SMEs in Laweyan, with its own character and quality. ${ }^{23}$ Below is the specification for their intended collective trademark.

Trademark name: Batik Heritage Laweyan

\section{Characteristics:}

I. Batik tulis (written batik), cap (stamped batik), and combination of written and stamped batik

II. Motif should have certain meaning

III. Construction of Cloth :

a. Cotton "primisima" min. of $133-72$

b. Rayon min. of $80-60$

c. Factory-made silk and loom non-machines

IV. The cloth should be strong and anti-fade

Authorized users : Members of FPKBL

Monitoring team : FPKBL

Procedure for inspection : Team can conduct inspection at anytime necessary

Sanction : In accordance with the prevailing laws and regulations

Table 1: Laweyan Batik Community's Collective Trademark Rules

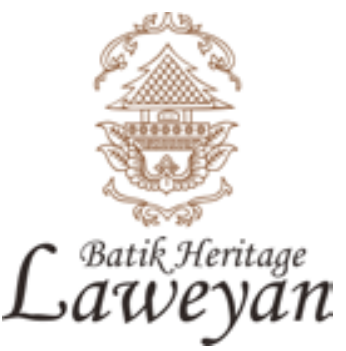

Picture 1: Laweyan Batik Community's Collective Mark/Label

${ }^{23}$ However, collective trademark should be differentiated with Geographical Indications. The collective trademark indicates certain SMEs as coming from particular community, group, or organization, while geographical indications indicate certain products as coming from certain area based on particular geographical (human or nature) factors that influence the quality of such products. git should be differentiated with Geographical Indications. This approach of using Collective Trademark for distinguishing and preserving different character and quality of a batik SMEs community may be continuously developed for all batik communities all around Indonesia. 


\section{Registration of Laweyan's Collective Trademark: Some Technical Issues}

\section{A. Applicants and Documents}

Basically there are two methods to register a trademark based on the Trademark Law. First, the applicant submit the registration application by him/herself, or second, he/she applies for registration through an IPR consultant. ${ }^{24}$ The applicants could be one or two/more persons (legal person), or a legal entity. In the case of Collective Trademark registration, the applicant cannot be a sole legal person. The applicants of Collective Trademark should be some number of persons, or a legal entity, whom all (altogether) trade similar goods/services. DGIPR did not establish any specific regulation for the procedure of Collective Trademark registration. The application can be submitted using the ordinary (individual) trademark application form (DGIPR does not issue a specific application form for Collective Trademark registration), and the differences are only in the substance of Statement Letter, and the requirement of Rules for the Use of Collective Trademark.

The Statement Letter should mention that the respective Collective Trademark belongs to some numbers of people, or a legal entity, altogether. However, for the application process, they can appoint one person as a representative whose identity information will be used in the documents for applications. ${ }^{25}$ If they have gathered in an organization, it is encouraged to enclose the organization's Deed of Establishment before the notary. The most important document distinguishing the application from an individual Trademark application is the Rules for the Use of Collective Trademark. As mentioned earlier, the Trademark Law regulates some issues that should be stipulated in the Rules, however it does not determine any specific format for the Rules, and so does DGIPR. Thus, the Collective Trademark applicants are free to create the Rules in any kind of format/form, yet must stipulate the respective issues obliged by the Trademark Law.

For Laweyan's Collective Trademark application, the applicant is FPKBL as the community's organization represented by its chairman. The chairman will act as the representative applicant and sign the Statement Letter and Power of Attorney on behalf of FPKBL. Members of FPKBL will be able to use the Collective Trademark. All of the members then also need to sign the Rules for the Use of Collective Trademark which they have agreed on.

\section{B. Difficulties in Collective Trademark's Application}

The applicants residing outside the domicile of DGIPR can submit their IPR applications to the regional office of Ministry of Law and Human Rights at their domiciles. They can also submit the applications directly to DGIPR, either by post or direct submission at the application desk. Direct submission at DGIPR office is much preferable because of these following reasons:

a. The application documents can be assessed directly by the application desk/

${ }^{24}$ An attorney specializing in IPR, or IPR consultant is someone who has an expertise in IPR, and specifically provide services for IPR assets' registrations, such as Patent, Trademark and Industrial Design. IPR consultants in Indonesia are registered in DGIPR.

${ }^{25}$ Since the mechanism allows those group of Collective Trademark applicants to give power of attorney to one person acting as a representative applicant for the registration's application, there is no need to provide all the group member's identity information and details. 
officials, so that the applicant can get much faster confirmation of whether all the required documents have been fulfilled.

b. The applicant can get information regarding the application fees accurately, so that over or underpayment will not happen.

c. The applicant can also directly pay the application fee since the bank's outlet for such payment is also available at DGIPR office.

d. Once the applicant's documents have been assessed and the fees are paid, the applicant can directly receive the application receipt from the application desk.

Direct submission to DGIPR office in Jakarta can be less complicated, especially in the case of Collective Trademark. This is because generally the officials have not been familiar with the applications and registration of Collective Trademarks. Considering its low number of applications compared with the Individual Trademarks, the officials' handling (behind the applications' desk) on Collective Trademark's applications may take longer time, since they may need to consult with the senior officials regarding some technical issue of Collective Trademark's applications. Furthermore, there has not been any technical instruction or manual for Collective Trademarks' applications. Thus, the administrative handling for the applications may require much more time than the individual ones. If the applicants file the applications directly at DGIPR office, they can ask for confirmation to the officials as soon as they submit the applications. In contrast, if the applicants submit the applications via postal service, it will be more difficult to ask for confirmations directly to the officials wether the application has been well received or not.

In regards to the applications' documents, the applicants also need to understand the class of goods and/or services they want to register under the Trademarks. They need to apply for certain class of goods and/or services which will use the Collective Trademarks. The class is based on the Nice Agreement, and consist of 45 (forty five) different classes. The applicants should choose the classes carefully based on their products, otherwise DGIPR officials will return their application documents for revisions. Collective Trademark's applications also require the Statement Letter. DGIPR has provided a template of Statement Letter in their website, however it is for an Individual Trademark application. Since there has not been a template for such letter for a Collective Trademark application, there is a risk that the Statement Letter of Collective Trademark that the applicants made does not meet with what DGIPR officials require. Therefore, the application process may take longer time because revisions to the documents are needed.

Particularly for Collective Trademark applications, the applicants need to understand about the Rules for the use of Collective Trademark. Even though the Trademark Law has mentioned the required issues that need to be addressed in such Rules, in preparing such Rules requires the applicants to have a skill of legal drafting, since the Rules may use specific and legal language. Therefore, the applicants need to cooperate or hire an IPR consultant or person with law background to help them making the Rules.

Considering such above mentioned complexities, the application for Laweyan's Collective Trademark will be involving an IPR consultant to help them making a direct submission to DGIPR office and preparing all the administrative documents, including preparing and drafting the Rules for the Use of Collective Trademark. 


\section{Method for Registering Collective Mark Effectively}

The essence of efficiency is the use of resources in order to have low excess and effectivity means the high accomplishment of the final result or target. In order to manage the trademark registration efficiently and effectively, there are several things to be considered. First is the distance between the applicant's domiciles to the DGIPR. Considering that to take care of the collective mark registration, the applicant will need to do some visits, if the the applicant's domicile is near to the DGIPR, the organization will be more efficient. Second, the knowledge and good skills in preparing the file. Most of the work done in trademark registration simply only to make copies of documents, such as the National Identity Card and brand's etiquette, which does not require special education and skills to do it. However, there are also works that require good understanding of trademark law and engineering design rules (legal drafting). The better mastery in the preparation of registration collective marks (namely the registration form, a statement of ownership of the brand, and the conditions of use of the collective mark), the more efficient will the maintenance be because the general registration process can be completed only with a single visit to the IP office. Third, personnel monitoring. In order for a brand to be able to have the status as a registered brand, the phases are quite long, which included administrative examination, announcement, substantive examination, and the decision of acceptance or rejection of the request. Hence trademark registration processing time is long enough. Moreover DGIPR also experiences the issue of back log. As the effect, the time frame until the decision stage of acceptance or rejection of a trademark registration is very long. In order for a trademark registration process can be well monitored, there should be personnel who directly come to the office DGIPR. Thus, the organization will be more efficient if the personnel who routinely perform routine monitoring of the process.

With reference to the three factors mentioned above, if the applicant has a domicile close to DGIPR office, has the knowledge and skills to prepare the entire file completeness of registration, and has personnel to perform routine monitoring, the implementation of trademark registration could be done alone by the applicant concerned. But when the three factors are not owned by the applicant, the applicant should provide power to the Intellectual Property Rights Consultant.

From the research that has been conducted on Batik SMEs Batikin Surakarta, in particular in Kampoeng Batik Laweyan, several facts were found:

a. The whole Batik's entrepreneurs in Laweyan did not understand the concept of trademark law. They did not understand very well the difference of each type of trademark, namely fanciful, arbitrary, persuasive, desctriptive and generic. They also did not understand very well the difference between individual mark with collective marks and between collective marks and geographical indications.

b. The whole Batik entrepreneurs in Laweyan never take care of their own individual mark registration. They focus on their business as manufacturers of batik and hand over the affairs of their trademark registrations on the professional, the Intellectual Property Rights Consultant.

c. Most Batik entrepreneurs in Laweyan initially thought that if there is a collective mark, then the entire batik in Laweyan can only be wearing the mark and can not use their individual mark. Socialization on this regard without giving an example of the implementation of the collective mark together with the individual mark within a product still confused them. However, after being given a concrete 
example, they instantly understand and are no longer had any misperception of collective marks.

d. Most Batik entrepreneurs in Laweyan initially did not support the existence of a collective mark, because they were not sure of the effectiveness of the legal protection in preventing act of imitation and fear of high costs. After understanding on how trademark could prevent the act of imitation and the acquisition of a collective mark is not costly, they supported the existence of a collective mark.

e. The whole Batik entrepreneurs in Laweyan did not have sufficient knowledge and skills in drafting the legal rules. Therefore, it is difficult for them to develop independently of their collective mark's terms of use.

f. The whole Batik entrepreneurs in Laweyan live and strive in Surakarta, while DGIPR's head office in Jakarta. Therefore, it is difficult for them to routinely monitor the trademark registration process that takes place in DGIPR.

Based on these findings, the terms of the three factors mentioned above, it can be concluded that the efficient and effective method of obtaining registration of a collective mark for SMEs in Kampoeng Batik Laweyan is through the Intellectual Property Rights Consultant.

\section{Method of Using Trademark Effectively}

Under Article 50 of Trademark Law, collective mark shall contain at least three things in its term of use:

1. The nature, a common characteristic, or quality of goods or services to be produced and traded;

2. The setting for the Collective Mark owners to conduct effective oversight of the use of the trademark;

3. Penalties for violations of the rules of use of Collective Marks.

Batik SMEs Batikin Laweyan do not easily understand the concept of the provisions related to the use of the collective mark of 'goods or services to be produced and traded'. In general, they equate it with the concept of Indonesian National Standards. Some are likening it to Geographical Indications. The difference between "trademark", "geographical indications", and "national standard" can be expressed as follows. First, there is a conceptual difference between them. Mark is a sign in the form of images, names, words, letters, numbers, color composition, or a combination of these elements, having distinguishing features and used in the trading of goods or services. Therefore, the main function of the mark is a sign which is used for distinguishing the products / manufacturers of products / manufacturers similar. Geographical Indication is a sign which indicates the origin of goods, which is due to the geographical environment, including natural factors or human factors or a combination of both factors, provide specific characteristics and quality of goods produced. ${ }^{26}$ In this case, geographical indications also serves as a 'sign', but can indicate the geographical origin of the product because of the special characteristics and quality of natural factors or human factors on the geographical region. Meanwhile, the Indonesian National Standard (SNI) is a standard set by the National Standardization Agency and applied nationally. SNI is stipulated in Government Regulation regarding National

${ }^{26}$ Indonesia, Undang-Undang tentang Merek (Law regarding Trademarks), UU No. 15 Tahun 2001, LN No. 110 Tahun 2001 (Law No. 15 Year 2001, SG No. 110 Year 2001), art. 56 (1). 
Standardization, Government Regulation No. 102 Year 2000, SG No. 197 Year 2000. For goods and or services, processes, systems and personnel who have met the requirements / technical specifications SNI can be given a certificate and or bore the SNI. Certificate itself is a written guarantee given by the institution / laboratory has been accredited to certify that the goods, services, processes, systems or personnels have met the required standards. Meanwhile, SNI mark is a certification mark affixed on the packaging or label goods are claimed to have fulfilled the requirements of the Indonesian National Standard. Types of certificate that can be given are certificate of test results, calibration certificate, certificate of quality systems, environmental management system certificate, certificate of product, personnel certificate, certificate of sustainable forest management, inspection certificate, and certificate. Second, there are differences as a result of the registration law. Registration of Trademark will give the owner of the trademark an exclusive right. SNI only indicates that the product complies with the national standards, but the owner of the product does not have the exclusive right for commercializing the product.

The term "trademark use" position is very important in trademark law. However, unfortunately in Trademark Law, the term is not defined precisely. Judging doctrinally, in scientific articles written by Margreth Barreth, it can be concluded that the use of a mark can be the use of technical and nontechnical use. The use of technical analysis includes but are not limited to, the use of measures of mark's label on the product, advertising of products, media promotional of products, product labels, product packaging, etc., by any means (printed, printed, chiseled, and so forth). While nontechnical use includes, but not limited to the act of impersonation visual packaging of a product without directly reproduce, in whole or in part of the mark's etiquette. The use of trademarks technically without permission of the owner, has globally accepted as a trademark infringement. However, to use the mark in nontechnical or often called passing off, not all countries explicitly set it as a violation of trademark rights. In relation to infringement of trademark, Barreth views that both trademark infringement and nontechnical nature, must meet at least two elements, namely the first, there is evidence that a defendant or suspect has the intention to defraud or deceive (fraudulent intent), and the second, there is evidence that the actions of the plaintiff or defendant has the potential to lead consumers to purchase or subscribe (consumer confusion). In Trademark Law, technically mark usage without permission of the owner, which must be expressly stated, is a trademark infringement, which may be subject to criminal sanctions and the owner can file a tort lawsuit. However, for use in a non-technical mark without permission of the owner, Trademark Law does not explicitly set as a violation of the rights of trademark law. Therefore, a rule which may be used is the provision of cheating in the Book of the Criminal Justice Act.

Trademark Law does not regulate the means of the owner of trademark rights to supervise the use of the mark; but it does regulate what to do if they find infringement of their rights. In civil law, every owner of a mark can respond to any misuse by sending a warning letter to those who commit the infringement. If the letter is not respected, the trademark owner can file a lawsuit of trademark tort to court. In criminal law, every mark owner can report anyone who presumed trademark infringement to the police or civil servants investigators who are responsible in the field of intellectual property rights. Therefore to prevent that kind of situation, every trademark owner needs to design, implement, and develop their own effective methods to monitor the use of his/her mark.

The supervision can be distinguished from the subject. First, supervision can be 
done by the owner of trademark rights themselves. The second, supervision is done by parties outside the trademark owner's rights. The owner of the trademark rights may conduct a self-monitoring by regularly conduct field observations to determine whether there is violation of rights. Usefulness of monitoring itself is that the trademark owner can directly determine the shape violations. But the drawback is that if the scope is very wide in marketing of its products, the implementation of the control itself will be costly. Weakness in the control by the owner can be overcome if the trademark owner can encourage initiative or voluntary participation of many parties outside himself. By building a community of loyal customers, the owner of trademark rights in the future will derive great benefit, because the loyal customers will inform the occurred trademark rights violations. The greater the incentive is given to outsiders who inform the trademark infringement, the better the ability to control the use of its mark will be.

In relation to the batik business run by the SMEs in Laweyan, the most effective method to monitor the use of their collective mark is the combination of its own supervision and managing feedback or report by external parties. By collecting information from the members of the collective mark owners regarding their distribution channels, the collective mark managers can determine the type of strategies that is most ideal to oversee the various distribution channels. To encourage feedback or report by external parties, collective mark managers of Laweyan should educate the public about the existence of a collective mark of Laweyan. Collective mark managers of Laweyan batik should make efforts to build the loyalty of customers, and then design a system where customers can easily report a violation of their collective mark. Collective mark managers also can give awards to each reporter, which will encourage their customers to make report of violation. Furthermore, to optimize the supervision, Laweyan collective mark managers need to cooperate actively with the local police and local legal aid institution in conductiong conducting law enforcement.

In relation to sanctions, this is an aspect that can not be controlled solely by the owner of trademark rights, if the dispute is resolved in court forum. This is because in any judicial proceedings, the imposition of sanctions is decided by the judges. However, if the violation occurred and the culprit is the internal management of collective marks, then the offense should be settled out of court and the sanctions can be set out wisely by the internal management of a collective mark. The last method is the most effective, because of the cheap cost, fast processing time, and sanctions can be immediately implemented.

\section{Conclusion}

Collective trademark registration is essentially not too different from the registration procedure with the individual mark. Until now DGIPR has not issued technical regulations or guidelines which specifically describe the collective trademark registration. However, based on interviews with the Director of Trademark DGIPR on 21 August 2014, DGIPR does not issue special registration form for collective marks. The differences between collective trademark registration and the individual trademark registration are in substance and their Statement Terms of Use Trademark Collective. In the Statement, applicants should mention that the collective mark which is to be registered is owned by several persons or legal entities together. The most important document which is different from the individual trademark registration is a legal agreement on Collective Marks. DGIPR does not create a standard format 
for the document; therefore each owner of collective mark may freely compose the agreement as long it does not in contrary with the Trademark Law.

There are at least three factors which affect the collective trademark registration method by Batik SMEs Batikwho want to register a collective mark to DGIPR. The third factor is the domicile of the applicant, the applicant's knowledge and ability to prepare complete files for registration, and the presence of personnel to monitor the progress of the application for registration. If those three things are not owned by the applicant, the applicant should provide power to the Intellectual Property Rights consultant to help him apply for registration of the mark. In this case, based on the findings in the field, method of obtaining registration of a collective mark an efficient and effective for SMEs in Kampoeng Batik Laweyan is through the Intellectual Property Rights consultant.

The term "trademark use" position is very important in trademark law. But unfortunately in Trademark Law, the term is not defined precisely. Trademark Law also does not regulate how the owner of trademark rights can supervise the use of the mark, but it does regulate what can be done if they find abuse of their rights. Being aware of that kind of situation, every trademark owner needs to design, implement, and develop their own effective methods to monitor the use of its mark. In relation to the batik business run by the SMEs in Laweyan, methods of monitoring the use of their collective mark of the most effective is a combination of its own supervision and oversight by external parties. By collecting information from the members of the collective mark owners regarding their distribution channels, the collective mark managers can devise strategies Laweyan field observations most ideal to oversee the various distribution channels. To streamline oversight by an external, collective mark manager Laweyan should educate the public about the existence of a collective mark Laweyan. Collective mark manager of Laweyan batik should attempt to have loyal customers, and then design a system where consumers can easily report a violation of a collective mark if they know; and to encourage the reporting initiatives, collective mark managers can give awards to each reporter.

\section{Bibliography}

\section{Legal Documents}

Indonesia. Undang-Undang tentang Merek (Law regarding Trademarks). UU No. 15 Tahun 2001, LN No. 110 Tahun 2001 (Law No. 15 Year 2001, SG No. 110 Year 2001).

\section{Books}

Butt, Simon. "Intellectual Property in Indonesia: A Problematic Legal Transplant" in Indonesia: Law and Society. Edited by Tim Lindsey. Sydney: Federation Press, 2008.

Peukert, Alexander. "The Competitive Significance of Collective Trademarks" in Individualism and Collectiveness in Intellectual Property Law. Edited by Jan Rosén. Cheltenham: Edward Elgar Publishing, 2011.

Singleton, Jr., Royce. et.al. Approaches to Social Research. Oxford: Oxford University Press: 1998.

Soekanto, Sorejono. Pengantar Penelitian Hukum. Depok: UI-Press, 2007. 


\section{Articles}

Gangjee, Dev. "Quibbling Siblings: Conflicts Between Trademarks and Geographical Indications." Chicago-Kent Law Review Vol. 82 No. 2 (January 2007): 1253-1291.

Jaszi, Peter. "Traditional Culture: A Step Forward for Protection in Indonesia." Washington College of Law Research Paper No. 2010-16 (May 2010). http:// papers.ssrn.com/sol3/papers.cfm?abstract_id=1617245.

Kusumadara, Afifah. 2000, "Konflik Hukum HKI dengan Adat di Indonesia." Jurnal Arena Hukum No. 12 (November 2000).

Rassenfosse, Gaétan de. "How SMEs Exploit Their Intellectual Property Assets: Evidence from Survey Data." Intellectual Property Research Institute of Australia Working Paper No. 8/10 (December 2010).

Sardjono, Agus. "Membangun Sinergi dalam Mengembangkan Industri Kreatif: Suatu Pendekatan Hukum (Empowering Synergy to Develop the Creative Industry: A Legal Approach)." Final Report of National Strategic Research Grant Year 2009.

Sardjono, Agus. et.al. "Pemanfaatan Hak Kekayaan Intelektual Oleh Pengusaha Kerajinan Mutiara di Lombok dan Kerajinan Rotan di Amuntai (Intellectual Property Rights Utilization by Pearl Craftsmen in Lombok, and Rattan Handicrafts in Amuntai)." Primary Grant Report of University of Indonesia's Leading Research Year 2012, Faculty of Law, University of Indonesia.

Situngkir, Hokky. "Deconstructing Javanese Batik Motif - When Traditional Heritage Meets Computation." Bandung Fe Institute (7 October 2008). http://papers. ssrn.com/sol3/papers.cfm?abstract_id=1312789.

Situngkir, Hokky. "Evolutionary Clustering in Indonesian Ethnic Textile Motifs." BFI Working Paper Series No. WP-VII-2008 (2008). http://papers.ssrn.com/sol3/ papers.cfm?abstract_id=1143142 .Steelyana, Evi. "Batik, A Beautiful Cultural Heritage that Preserve Culture and Support Economic Development in Indonesia." Binus Business Review Vol. 3 No. 1 (May 2012).

World Intellectual Property Organization. "Making a Mark: An Introduction to Trademarks for Small and Medium-sized Enterprises." Intellectual Property for Business Series No. 1. http://www.wipo.int/export/sites/www/sme/en/ documents/guides/translation/making a mark indo.pdf. Accessed 4 July 2013.

\section{Websites}

Detikfinance. "RI Digempur Batik China Sejak 4 Tahun Lalu." http://finance.detik. com/read/2013/02/20/133528/2175015/4/ri-digempur-batik-china-sejak4-tahun-lalu.

Detikfinance. "Tanggapi Serbuan Batik Impor, Menteri Bappenas: Itu Bukan Batik!" http://finance.detik.com/read/2013/02/20/115057/2174877/4/tanggapiserbuan-batik-impor-menteri-bappenas-itu-bukan-batik. Accessed 20 Februari 2013.

Khairi, Riza "Batik China dan Bawang Putih Impor Banjiri Indonesia, Ini Tanggapan Bos Kadin." http://suarapengusaha.com/2013/02/27/batik-china-danbawang-putih-impor-banjiri-indonesia-ini-tanggapan-bos-kadin/. Accessed 11 Maret 2013.

Okezone. "Gubernur Jateng Keluhkan Serbuan Batik Impor China." http://jakarta. okezone.com/read/2011/10/03/320/510056/gubernur-jateng-keluhkanserbuan-batik-impor-china.

RMOL. "Batik China dan Jiran Ganggu Daya Saing Produk Lokal.” http://ekbis.rmol.co/ $\mathrm{read} / 2011 / 08 / 03 / 35131 /$ Batik-China-\&-Jiran-Ganggu-Daya-Saing-ProdukLokal-.

The Indonesian Way. "Impor Batik dari China Mencapai Rp 285 Miliar." http://www. theindonesianway.com/impor-batik-dari-china-mencapai-rp-285-miliar/. 